\title{
ANALISIS FAKTOR-FAKTOR YANG MEMPENGARUHI LEVEL INTERNET ADDICTION DISORDER PADA SISWA SMA NEGERI 42 JAKARTA
}

\author{
Zuhana Realita Alfy \\ Program Studi Informatika, Universitas Indraprasta PGRI \\ realitaalfi@gmail.com
}

\begin{abstract}
Abstrak
Selain memberikan kemudahan di segala bidang, internet ternyata juga memiliki dampak negatif. Internet Addiction Disorder merujuk kepada pola penggunaan internet yang berlebihan dan mengganggu kehidupan dari pengguna internet itu sendiri. Penelitian ini ditunjukan untuk mengetahui level Internet Addiction Disorder pada siswa SMA Negeri 42 Jakarta beserta karakteristiknya dan faktor-faktor yang mempengaruhi level Internet Addiction Disorder tersebut. Analisis yang digunakan adalah analisis deskriptif dan analisis regresi logistik multinomial. Hasil penelitian ini menunjukkan bahwa sebagian besar siswa SMA Negeri 42 Jakarta menderita Internet Addiction Disorder pada level Moderate. Terdapat faktor-faktor yang mempengaruhi level Internet Addiction Disorder yaitu motif penggunaan internet, lama menjadi user, kualitas hubungan dengan teman, dan penghasilan orang tua teman sebaya sangat mempengaruhi perilaku remaja termasuk perilaku dalam penggunaan internet.
\end{abstract}

Kata Kunci : Internet, Internet Addiction Disorder, Regresi Logistik Multinomial

\begin{abstract}
In addition to providing convenience in all fields, the internet also has a negative impact. Internet Addiction Disorder refers to the pattern of excessive internet usage and disrupts the lives of internet users themselves. This research was shown to determine the level of Internet Addiction Disorder in Jakarta 42 Senior High School students along with their characteristics and factors that influence the level of the Internet Addiction Disorder. The analysis used was descriptive analysis and multinomial logistic regression analysis. The results of this research indicate that the majority of Jakarta State High School 42 students suffer from Internet Addiction Disorder at the Moderate level. There are factors that influence the level of Internet Addiction Disorder, namely the motive for using the internet, the length of time being a user, the quality of relationships with friends, and the income of peers parents greatly influencing adolescent behavior including behavior in internet usage.
\end{abstract}

Key Words : Internet, Internet Addiction Disorder, Multinomial Logistic regression

\section{PENDAHULUAN}

Teknologi informasi dan komunikasi yang berkembang pesat saat ini adalah internet [1]. Internet telah mengalami perkembangan yang pesat dimulai sejak terbentuknya pada tahun 1990-an sampai dengan sekarang. Seiring dengan perkembangan internet, fasilitas yang ditawarkan pun menjadi semakin beragam. Fasilitas tersebut di antaranya mencakup browsing, email, mailing list, chatting, newsgroup, file transfer, teleconference, internet telephony, internet fax, dan social networking. Kemudahan fasilitas yang disediakan oleh internet ini menyebabkan semakin banyak orang tertarik untuk menggunakan internet.

Selain memberikan kemudahan di segala bidang, internet ternyata juga memiliki dampak negatif terutama apabila penggunaannya dilakukan secara berlebihan. Penelitian-penelitian terbaru mulai meneliti berbagai konsekuensi dari penggunaan internet yang berlebihan. Beragam istilah seperti Internet Addiction, Internet Addiction Disorder, Pathalogical Internet Use, Excessive Internet Use, dan Compulsive Internet Use menarik perhatian banyak peneliti. Istilah-istilah tersebut merujuk ke pola penggunaan 
internet yang berlebihan dan mengganggu kehidupan dari pengguna internet itu sendiri. Badan himpunan psikologi yang berada di Amerika serikat menyebutkan bahwa Internet Addiction dianggap sebagai suatu Mental disorder (gangguan kejiwaan) yang kemudian disebut sebagai Internet Addiction Disorder. Umumnya seseorang yang mengalami Internet Addiction Disorder akan kesulitan dalam mengembangkan kemampuan atau kecakapannya dalam berhubungan dengan orang lain sehingga membuat hubungan sosial dan interaksi mereka dengan keluarga, teman dan orang disekitarnya menjadi kurang baik serta mengalami prestasi akademik yang menurun dan akan mengalami kepanikan, kurang percaya diri, stres, bahkan bunuh diri [2].

Pengguna internet tersebut sulit lepas dari penggunaan internet, mereka merasa tidak nyaman bila tidak menggunakan internet. Untuk mendapatkan kepuasan dari penggunaan internet maka tanpa disadari jumlah waktu yang dihabiskan untuk mengakses internet juga semakin bertambah. Seperti halnya orang yang kecanduan alkohol dan judi, kecanduan terhadap internet juga dapat menjadi pemicu seseorang melakukan tindak kriminal.

Setiap pengguna internet memiliki resiko untuk terkena Internet Addiction Disorder. Segala fasilitas yang ditawarkan oleh internet membuat pengguna internet enggan untuk beranjak dari dunia maya. Sering kali tanpa sadar pengguna internet menghabiskan waktunya berjam-jam di depan komputer atau dengan smartphonenya.

Semakin bertambahnya jumlah pengguna internet yang ada di Indonesia, maka hal ini memungkinkan peluang terjadinya Internet Addiction Disorder yang lebih besar. Mengingat remaja sebagai pihak yang paling beresiko terkena Internet Addiction Disorder, perlu diwaspadai terjadinya Internet Addiction Disorder pada remaja Indonesia. Mengapa remaja merupakan salah satu kelompok yang paling beresiko untuk menderita Internet Addiction Disorder?. Pada masa remaja, terjadi peralihan dari masa kanak-kanak menuju masa kedewasaan. Pada masa ini remaja mulai berintegrasi dengan masyarakat dewasa, dalam hal ini remaja merasa berada pada tingkatan yang sama dengan orang dewasa lainnya. Sehingga remaja merasa memiliki hak untuk melakukan hal-hal yang disukainya. Remaja mulai mencoba hal-hal yang baru baginya. Salah satunya adalah metode komunikasi yang baru yaitu komunikasi yang dimana batasan ruang, jarak, dan waktu tidak ada lagi.

Dilihat dari segi usia, remaja termasuk dalam usia sekolah, yakni sebagai pelajar ataupun mahasiswa. Mereka yang terkena Internet Addiction Disorder mengalami penurunan nilai, bahkan tinggal kelas ataupun Drop Out dari kampusnya, berkurangnya waktu tidur karena on-line sehingga tidak konsentrasi belajar saat di kelas, frekuensi bersosialisasi dengan teman-temannya berkurang, menjadi tidak aktif mengikuti kegiatan-kegiatan di sekolah ataupun di kampus, dan mereka menganggap bahwa apa yang mereka dapatkan di internet lebih baik dari apa yang mereka dapatkan di kelas.

Penelitian yang telah dilakukan oleh Basri, menyimpulkan bahwa terdapat hubungan yang signifikan dan negatif antara religiositas dengan kecenderungan Internet Addiction Disorder yang dibuktikan dengan hasil perbandingan hipotesa menggunakan uji $\mathrm{t}$ menunjukkan bahwa terdapat perbedaan dilihat dari jenis kelamin. Perbandingan tingkat religiositas pada mahasiswa perempuan lebih tinggi dibandingkan dengan laki-laki, perempuan 
memiliki kecenderungan Internet Addiction Disorder lebih tinggi dibandingkan dengan laki-laki [3].

Selanjutnya penelitian yang telah dilakukan oleh Arisandy, menyimpulkan bahwa terdapat hubungan yang negatif antara kecanduan internet dengan kontrol diri pada mahasiswa Universitas Bina Darma. Hal ini berarti bahwa semakin tinggi kecanduan internet maka semakin rendah tingkat kontrol diri mahasiswa tersebut, begitupun sebaliknya semakin rendah kecanduan internet maka mahasiswa tersebut memiliki tingkat kontrol diri yang semakin tinggi [4].

Pada remaja yang menderita Internet Addiction Disorder akan terjadi kelelahan otak berlebih. Kelelahan ini terjadi pada bagian otak Prefrontal Dorsolateral, bagian otak ini berperan penting pada fungsi eksekutif otak, meliputi fungsi untuk perencanaan, pengambilan keputusan, dan pemecahan masalah. Fungsi ini tentunya sangat penting pada remaja yang merupakan pelajar SMA. Jika fungsi ini tidak dapat terlaksana dengan baik, tentunya akan memengaruhi prestasi belajar di sekolah.

Berdasarkan survei yang dilakukan di SMA Negeri 42 Jakarta, di antara 113 sampel terdapat 35 siswa yang penggunaan internetnya di atas 19 jam per minggu (sekitar 30,9\%). Hal ini mengindikasikan bahwa terdapat Internet Addiction Disorder pada remaja di SMA Negeri 42 Jakarta.

Seperti yang telah dijelaskan sebelumnya, bahwa masalah akademis, sosial, dan keuangan yang merupakan konsekuensi negatif dari Internet Addiction Disorder cukup mengkhawatirkan. Padahal seperti yang kita ketahui, pelajar yang merupakan generasi muda memegang peranan penting sebagai generasi penerus bangsa. Untuk itu perlu diperhatikan mengenai adanya Internet Addiction Disorder pada remaja SMA agar generasi penerus bangsa dapat memiliki masa depan yang cerah dan membawa bangsanya menuju kesejahteraan dan kemakmuran.

Dengan melihat permasalahan diatas, untuk itu penulis tertarik untuk melakukan penelitian tersebut yang bertujuan untuk mengetahui level Internet Addiction Disorder yang diderita oleh siswa SMA Negeri 42 Jakarta, dan mengetahui faktorfaktor yang mempengaruhi level Internet Addiction Disorder pada siswa SMA Negeri 42 Jakarta.

\section{METODE}

Penelitian ini merupakan penelitian survey dengan pendekatan kuantitatif dan kualitatif. Penelitian ini diadakan di SMA Negeri 42 Jakarta. Teknik sampling yang digunakan didalam penelitian ini adalah metode penarikan sampel acak berlapis (stratified random sampling).

Teknik pengumpulan data menggunakan instrument yang sebelumnya telah diuji kevaliditasannya. Instrument yang digunakan berupa kuesioner. Kuesioner yang digunakan dalam penelitian ini terdiri dari dua jenis, yaitu kuesioner listing dan kuesioner survei inti. Kuesioner listing digunakan untuk mendapatkan kerangka sampel yang lengkap dengan informasi level Internet Addiction Disorder dari setiap elemen populasi. Kuesioner survei inti digunakan untuk mengumpulkan data mengenai variabel-variabel lain yang digunakan dalam penelitian ini.

Selanjutnya instrument yang sudah diuji validasinya tersebut disebarkan kepada responden, untuk kemudian hasilnya ditabulasi dan dilakukan analisis data. Data yang diperoleh selanjutnya dilakukan uji hipotesis dan kemudian dianalisis dengan metode regresi logistik multinomial. Pada 
regresi logistik multinomial, suatu variabel dependen dengan $\mathrm{j}$ kategori akan membentuk persamaan logit sebanyak $\mathrm{j}-1$ di mana masing-masing persamaan ini membentuk regresi logistik biner yang membandingkan suatu kelompok kategori terhadap kategori referensi.

\section{HASIL DAN PEMBAHASAN}

\section{Analisis deskriptif}

Analisis deskriptif dalam penelitian ini digunakan untuk memberikan gambaran mengenai karakteristik umum remaja berdasarkan level Internet Addiction Disorder. Pengukuran level Internet Addiction Disorder dilakukan bersamaan dengan pembentukan kerangka sampel. Sehingga pengukuran ini dapat diterapkan untuk keseluruhan populasi.

Berdasarkan pengukuran yang telah dilakukan, diperoleh hasil sebagai berikut :

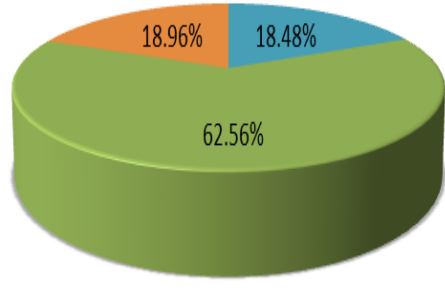

घMild $\square$ Moderate $\square$ Severe

\section{Gambar 1. Persentase Level Internet Addiction Disorder pada siswa SMA Negeri 42 Jakarta}

Berdasarkan gambar di atas, terlihat bahwa 62.56 persen dari siswa SMA Negeri 42 Jakarta menderita Internet Addiction Disorder pada level Moderate, 18.96 persennya masuk ke dalam level Severe, dan 18.48 persennya masuk ke dalam level Mild. Hal ini menggambarkan bahwa sebagian besar dari populasi menderita Internet Addiction Disorder pada level Moderate.

Artinya sebagian besar dari siswa SMA Negeri 42 Jakarta sering mengalami masalah yang disebabkan oleh penggunaan internetnya. Dan hanya sebagian kecil yang mampu mengontrol penggunaan internetnya. Serta sebagian kecilnya lagi mengalami masalah yang signifikan yang disebabkan oleh penggunaan internet.

\section{Pengujian Hipotesis}

Tabel 1. Output Regresi Logistik Multinomial

\begin{tabular}{|c|c|c|c|}
\hline \multicolumn{4}{|c|}{ Case Processing Summary } \\
\hline & & $\mathrm{N}$ & $\begin{array}{l}\text { Marginal } \\
\text { Percentage }\end{array}$ \\
\hline \multirow[t]{3}{*}{ Level IAD } & SEVERE & 40 & $19.3 \%$ \\
\hline & MODERATE & 129 & $62.3 \%$ \\
\hline & MILD & 38 & $18.4 \%$ \\
\hline \multirow{2}{*}{$\begin{array}{l}\text { Jenis } \\
\text { Kepribadian }\end{array}$} & EKSTROVERT & 135 & $65.2 \%$ \\
\hline & INTROVERT & 72 & $34.8 \%$ \\
\hline \multirow[t]{2}{*}{ Jenis Kelamin } & LAKI-LAKI & 99 & $47.8 \%$ \\
\hline & PEREMPUAN & 108 & $52.2 \%$ \\
\hline \multirow{4}{*}{$\begin{array}{l}\text { Uang saku per } \\
\text { bulan }\end{array}$} & $<250 \mathrm{RB}$ & 33 & $15.9 \%$ \\
\hline & $250-350 \mathrm{RB}$ & 80 & $38.6 \%$ \\
\hline & $350-500 \mathrm{RB}$ & 66 & $31.9 \%$ \\
\hline & $>500 \mathrm{RB}$ & 28 & $13.5 \%$ \\
\hline \multirow{16}{*}{$\begin{array}{l}\text { Waktu luang per } \\
\text { hari }\end{array}$} & 1 & 3 & $1.4 \%$ \\
\hline & 2 & 13 & $6.3 \%$ \\
\hline & 3 & 30 & $14.5 \%$ \\
\hline & 4 & 47 & $22.7 \%$ \\
\hline & 5 & 23 & $11.1 \%$ \\
\hline & 6 & 24 & $11.6 \%$ \\
\hline & 7 & 13 & $6.3 \%$ \\
\hline & 8 & 15 & $7.2 \%$ \\
\hline & 9 & 5 & $2.4 \%$ \\
\hline & 10 & 7 & $3.4 \%$ \\
\hline & 11 & 3 & $1.4 \%$ \\
\hline & 12 & 12 & $5.8 \%$ \\
\hline & 13 & 6 & $2.9 \%$ \\
\hline & 14 & 2 & $1.0 \%$ \\
\hline & 15 & 2 & $1.0 \%$ \\
\hline & 16 & 2 & $1.0 \%$ \\
\hline \multirow{2}{*}{$\begin{array}{l}\text { Penghasilan Org } \\
\text { tua per bulan }\end{array}$} & <Rp. 3 Juta & 55 & $26.6 \%$ \\
\hline & $\begin{array}{l}\text { Rp. } 3 \text { Juta - Rp. } \\
5 \text { Juta }\end{array}$ & 78 & $37.7 \%$ \\
\hline
\end{tabular}




\begin{tabular}{|c|c|c|c|}
\hline & $\begin{array}{l}\text { Rp. } 5 \text { Juta - Rp. } \\
\text { 10 Juta }\end{array}$ & 55 & $26.6 \%$ \\
\hline & $>$ Rp. 10 Juta & 19 & $9.2 \%$ \\
\hline \multirow{2}{*}{ Pengawasan } & YA & 133 & $64.3 \%$ \\
\hline & TIDAK & 74 & $35.7 \%$ \\
\hline \multirow{4}{*}{$\begin{array}{l}\text { Tempat akses } \\
\text { internet }\end{array}$} & WARNET & 45 & $21.7 \%$ \\
\hline & RUMAH & 148 & $71.5 \%$ \\
\hline & SEKOLAH & 4 & $1.9 \%$ \\
\hline & LAINNYA & 10 & $4.8 \%$ \\
\hline \multirow{3}{*}{$\begin{array}{l}\text { Media akses } \\
\text { internet }\end{array}$} & BERBAYAR & 154 & $74.4 \%$ \\
\hline & HANDPHONE & 43 & $20.8 \%$ \\
\hline & $\begin{array}{l}\text { WIFI, } \\
\text { HOTSPOT }\end{array}$ & 10 & $4.8 \%$ \\
\hline \multirow{4}{*}{$\begin{array}{l}\text { Lama menjadi } \\
\text { user }\end{array}$} & $<1 \mathrm{TH}$ & 13 & $6.3 \%$ \\
\hline & $1-2 \mathrm{TH}$ & 48 & $23.2 \%$ \\
\hline & $3-4 \mathrm{TH}$ & 77 & $37.2 \%$ \\
\hline & $>4 \mathrm{TH}$ & 69 & $33.3 \%$ \\
\hline \multirow{3}{*}{$\begin{array}{l}\text { Motif } \\
\text { penggunaan } \\
\text { internet }\end{array}$} & HIBURAN & 88 & $42.5 \%$ \\
\hline & SOSIAL & 55 & $26.6 \%$ \\
\hline & PENDIDIKAN & 64 & $30.9 \%$ \\
\hline \multirow[t]{6}{*}{ Fasilitas Internet } & $\begin{array}{l}\text { BROWSING/S } \\
\text { URFING }\end{array}$ & 55 & $26.6 \%$ \\
\hline & EMAIL & 3 & $1.4 \%$ \\
\hline & CHATTING & 19 & $9.2 \%$ \\
\hline & $\begin{array}{l}\text { NEWSGROUP, } \\
\text { MAILING LIST }\end{array}$ & 4 & $1.9 \%$ \\
\hline & $\begin{array}{l}\text { JEJARING } \\
\text { SOSIAL }\end{array}$ & 113 & $54.6 \%$ \\
\hline & $\begin{array}{l}\text { FILE } \\
\text { TRANSFER }\end{array}$ & 13 & $6.3 \%$ \\
\hline \multirow[t]{2}{*}{ Kontrol diri } & TINGGI & 172 & $83.1 \%$ \\
\hline & RENDAH & 35 & $16.9 \%$ \\
\hline \multirow{2}{*}{$\begin{array}{l}\text { Kualitas hbgn } \\
\text { dgn teman }\end{array}$} & TINGGI & 200 & $96.6 \%$ \\
\hline & RENDAH & 7 & $3.4 \%$ \\
\hline \multirow{2}{*}{$\begin{array}{l}\text { Kualitas hbgn } \\
\text { dgn ortu dan } \\
\text { keluarga }\end{array}$} & TINGGI & 187 & $90.3 \%$ \\
\hline & RENDAH & 20 & $9.7 \%$ \\
\hline Valid & & 207 & $100.0 \%$ \\
\hline Missing & & 0 & \\
\hline Total & & 207 & \\
\hline Subpopulation & & $206^{\mathrm{a}}$ & \\
\hline
\end{tabular}

a. The dependent variable has only one value observed in $205(99.5 \%)$ subpopulations.

Pengujian dilakukan dengan menggunakan software SPSS 16.0. Pada pengujian ini digunakan metode Backward Elimination, yaitu memasukkan semua variabel independen kedalam model kemudian mengeluarkan variabel independen yang tidak signifikan secara satu per satu.

\section{Tabel 2. Metode Backward Elimination}

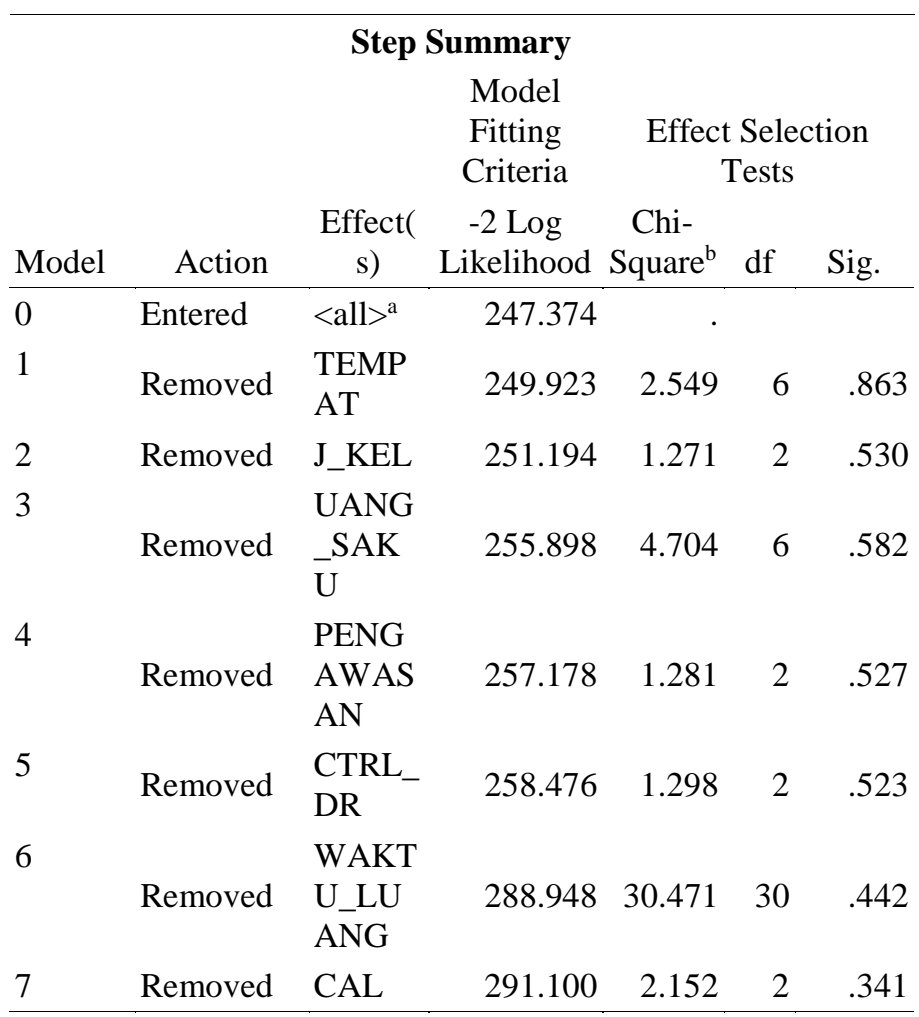

Stepwise Method: Backward Elimination

a. This model contains all effects specified or implied in the MODEL subcommand.

b. The chi-square for removal is based on the likelihood ratio test.

Tabel Likelihood Ratio Test memberikan informasi mengenai kontribusi setiap variabel independen terhadap model. Variabel motif penggunaan internet, penghasilan orang tua, lama menjadi user, dan kualitas hubungan dengan teman memberikan pengaruh yang signifikan terhadap model. Hal ini terlihat dari nilai sig. yang lebih kecil dari 0,05. 
Tabel 3. Likelihood Ratio Tests

\begin{tabular}{|c|c|c|c|c|}
\hline \multicolumn{5}{|c|}{ Likelihood Ratio Tests } \\
\hline & $\begin{array}{l}\text { Model } \\
\text { Fitting } \\
\text { Criteria }\end{array}$ & Likelihood & Ratio & Tests \\
\hline Effect & $\begin{array}{c}-2 \log \\
\text { Likelihood } \\
\text { of Reduced } \\
\text { Model }\end{array}$ & Chi-Square & $\mathrm{df}$ & Sig. \\
\hline Intercept & $2.911 \mathrm{E} 2^{\mathrm{a}}$ & .000 & 0 & \\
\hline KELUARGA & 295.937 & 4.838 & 2 & .089 \\
\hline MOTIF & 308.536 & 17.436 & 4 & .002 \\
\hline MEDIA & 299.607 & 8.507 & 4 & .075 \\
\hline $\begin{array}{l}\text { PENGHASILA } \\
\mathrm{N}\end{array}$ & 302.028 & 10.928 & 6 & .041 \\
\hline LAMA_USER & 324.851 & 33.751 & 6 & .000 \\
\hline FASILITAS & 307.316 & 16.216 & 10 & .094 \\
\hline TEMAN & 296.399 & 5.299 & 2 & .031 \\
\hline
\end{tabular}

The chi-square statistic is the difference in $-2 \log$ likelihoods between the final model and a reduced model. The reduced model is formed by omitting an effect from the final model. The null hypothesis is that all parameters of that effect are 0 .

a. This reduced model is equivalent to the final model because omitting the effect does not increase the degrees of freedom.

\section{Pembahasan}

Berdasarkan hasil analisis di atas, dari 14 variabel yang diteliti dalam penelitian ini, terdapat 4 variabel yang signifikan memengaruhi level Internet Addiction Disorder pada siswa SMA Negeri 42 Jakarta. Variabel-variabel tersebut adalah motif penggunaan internet, lama menjadi user, kualitas hubungan dengan teman, dan penghasilan orang tua.

Motif penggunaan internet secara signifikan berpengaruh terhadap Internet Addiction Disorder pada level Moderate maupun Internet Addiction Disorder pada level Severe. Siswa SMA Negeri 42 Jakartayang menggunakan internet karena motif hiburan lebih cenderung untuk menderita Internet Addiction Disorder pada level Severe dibandingkan remaja yang menggunakan internet karena motif pengetahuan. Sedangkan remaja yang menggunakan internet karena motif hiburan ataupun sosial lebih cenderung untuk menderita Internet Addiction Disorder pada level Moderate dibandingkan siswa SMA Negeri 42 Jakarta yang menggunakan internet karena motif pengetahuan.

Lama menjadi user juga berpengaruh secara signifikan pada level Moderate maupun Severe. Siswa SMA Negeri 42 Jakarta yang menggunakan internet kurang dari 1 tahun memiliki kecenderungan yang lebih besar untuk menderita Internet Addiction Disorder pada level Moderate dibandingkan siswa SMA Negeri 42 Jakarta yang telah menggunakan internet lebih dari 4 tahun. Nampaknya, teknologi internet yang terbilang baru bagi mereka memiliki daya tarik tersendiri sehingga mereka tertantang untuk mengeksplorasi internet lebih lanjut.

Siswa SMA Negeri 42 Jakarta yang telah menggunakan internet selama $1 \mathrm{~s} / \mathrm{d} 2$ tahun memiliki kecenderungan yang lebih kecil untuk menderita Internet Addiction Disorder pada level Moderate maupun Severe dibandingkan siswa SMA Negeri 42 Jakarta yang telah menggunakan internet lebih dari 4 tahun. Bagitu pula dengan siswa SMA Negeri 42 Jakarta yang telah menggunakan internet selama $3 \mathrm{~s} / \mathrm{d} 4$ tahun, mereka memiliki kecenderungan yang lebih kecil untuk menderita Internet Addiction Disorder pada level Severe dibandingkan siswa SMA Negeri 42 Jakarta yang menggunakan internet lebih dari 4 tahun.

Hal yang cukup menarik yaitu siswa SMA Negeri 42 Jakarta yang menggunakan internet kurang dari 1 tahun memiliki kecenderungan yang hampir sama dengan siswa yang telah menggunakan internet lebih dari 4 tahun untuk menderita Internet Addiction Disorder pada level Severe. 
Nampaknya user yang memiliki ketertarikan untuk mengeksplorasi internet lebih lanjut dan user yang telah lama menggunakan internet lebih dari 4 tahun memiliki level Internet Addiction Disorder yang lebih parah.

Hal ini mungkin disebabkan karena ketertarikan yang besar untuk mengeksplorasi internet lebih jauh menyebabkan user lebih terlibat dalam dunia maya sedangkan user yang telah menggunakan internet lebih dari 4 tahun tentunya lebih menguasai dan berpengalaman menggunakan internet. Mereka yang telah menggunakan internet lebih dari 4 tahun tentunya lebih leluasa dan terbiasa menggunakan fasilitasfasilitas internet sehingga lebih bergantung pada kemudahan yang disediakan oleh internet.

Terdapat pula variabel-variabel yang berpengaruh secara signifikan hanya terhadap salah satu level Internet Addiction Disorder. Penghasilan orang tua secara signifikan memengaruhi Internet Addiction Disorder pada level Moderate. Siswa SMA Negeri 42 Jakarta dengan penghasilan orang tua kurang dari Rp. 3.000 .000 per bulan memiliki kecenderungan yang lebih kecil untuk menderita Internet Addiction Disorder pada level Moderate dibandingkan siswa SMA Negeri 42 Jakarta dengan orang tua yang berpenghasilan lebih dari Rp. 5.000 .000 per bulan.

Penghasilan orang tua yang kecil menyebabkan keterbatasan remaja dalam mengakses internet yang umumnya diakses melalui layanan berbayar. Sedangkan siswa SMA Negeri 42 Jakarta dengan penghasilan orang tua antara Rp. 3.000.000 sampai dengan Rp. 5.000.000 memiliki kecenderungan yang lebih besar untuk menderita Internet Addiction Disorder pada level Moderate dibandingkan siswa
SMA Negeri 42 Jakarta dengan penghasilan orang tua lebih dari Rp. 5.000.000. Dengan penghasilan yang cukup besar, orang tua mampu memenuhi kebutuhan anak termasuk kebutuhan akan internet.

Kualitas hubungan dengan teman juga berpengaruh secara signifikan terhadap level Internet Addiction Disorder Moderate. Siswa SMA Negeri 42 Jakarta yang memiliki kualitas hubungan yang tinggi dengan temannya memiliki kecenderungan yang sangat besar untuk menderita Internet Addiction Disorder pada level Moderate dibandingkan siswa SMA Negeri 42 Jakarta yang memiliki kualitas hubungan yang rendah dengan temannya.

Teman sebaya (Peer Group) memiliki pengaruh yang besar terhadap perilaku dan arah hidup remaja. Jika remaja berada dalam lingkungan pergaulan yang positif, maka perilaku dan sikap remaja umumnya akan ikut menjadi positif, sebaliknya jika remaja berada dalam lingkungan pergaulan yang negatif maka perilaku dan sikapnya akan menjadi negatif.

Begitu pula kaitannya dengan Internet Addiction Disorder. Jika remaja berada dalam lingkungan sosial di mana teman sebayanya banyak yang menderita Internet Addiction Disorder pada level Moderate, maka besar kemungkinan remaja tersebut juga akan menderita Internet Addiction Disorder pada level Moderate.

\section{SIMPULAN}

Berdasarkan penelitian yang telah dilakukan, maka didapatkan beberapa kesimpulan mengenai Internet Addiction Disorder pada siswa SMA Negeri 42 Jakarta. Kesimpulan tersebut antara lain adalah sebagai berikut :

1. Sebanyak 62.56 persen siswa SMA Negeri 42 Jakarta menderita Internet 
Addiction Disorder pada level Moderate. Sedangkan 18.96 persennya menderita Internet Addiction Disorder pada level Severe, dan 18.48 persen pada level Mild.

2. Karakteristik siswa SMA Negeri 42 Jakarta berbeda-beda menurut level Internet Addiction Disorder yang dideritanya. Level Mild didominasi oleh mereka yang menggunakan internet dengan motif pengetahuan, menggunakan fasilitas email, kualitas hubungan sosial yang rendah, memiliki kontrol diri tinggi, dan jumlah uang saku serta penghasilan orang tua yang rendah. Level Moderate didominasi oleh mereka yang menggunakan internet dengan motif hiburan, menggunakan bermacam fasilitas internet (kecuali fasilitas email), kualitas hubungan sosial yang tinggi, dan memiliki kontrol diri tinggi. Sedangkan level Severe didominasi oleh mereka yang menggunakan internet dengan motif hiburan, menggunakan fasilitas chatting, kualitas hubungan dengan teman yang rendah, kualitas hubungan dengan orang tua dan keluarga yang tinggi, dan memiliki kontrol diri yang rendah.
3. Motif penggunaan internet, lama menjadi user, kualitas hubungan dengan teman, dan penghasilan orang tua memengaruhi level Internet Addiction Disorder pada siswa SMA Negeri 42 Jakarta.

\section{DAFTAR PUSTAKA}

[1] S. Ameliola and H. D. Nugraha. Perkembangan Media Informasi Dan Teknologi Terhadap Anak Dalam Era Globalisasi. The $5^{\text {th }}$ Internasional Conference On Indonesian Studies: "Ethnicity And Globalization"Ity And Globalization" 362-371, 2013.

[2] N. Jannah, Mudjiran, and H. Nirwana. "Hubungan Kecanduan Games Dengan Motivasi Belajar Siswa Dan Implikasinya Terhadap Bimbingan dan Konseling". Konselor, 4 (4) , 200-207, 2015.

[3] A. S. H. Basri. "Kecenderungan Internet Addiction Disorder Mahasiswa Fakultas Dakwah dan Komunikasi Ditinjau Dari Religiositas". Jurnal Dakwah, XV(2), 407-432, 2015.

[4] D. Arisandy. "Hubungan Antara Kontrol Diri Dengan Kecanduan Internet Pada Mahasiswa Universitas Bina Darma Tahun 2009 Palembang". Naskah Publikasi 1-13, 2009 